\title{
Understanding Concepts of Multiplication Number for Slow Learner Student Through Meaningful Learning at Inclusion School
}

\author{
Ukhti Raudhatul Jannah ${ }^{1}$, Hasan Basri ${ }^{2}$, Ainur Rofiq Hafsi ${ }^{3}$, Yanti Linarsih ${ }^{4}$, Mila \\ Rifa Utami ${ }^{5}$ \\ 1, 2, 5 Program Studi Pendidikan Matematika, FKIP, Universitas Madura, Indonesia \\ ${ }^{3,4}$ Pendidikan Bahasa Indonesia, FKIP, Universitas Madura, Indonesia \\ *Corresponding author. Email: ukhti_math@unira.ac.id
}

\begin{abstract}
This study was to describe the multiplication of numbers through meaningful learning for disabled students in inclusion school. This is based on the results of preliminary observations at Primary School Sumedangan 2 Pamekasan as one of the inclusions school, the fact is that in sixth grade there are normal students and one with special need (slow learner with speech limitations). The ability of these slow learners is very minimal in mathematics, especially in understanding the concept of multiplying numbers (multiplication 1 to 10). In addition, these slow learners have not been able to achieve the expected competency standards and basic competencies. This research is a case study with the research subject is 1 slow learner. Data collection techniques were student worksheets, tests, and interviews. This research was conducted face to face at the research subject's house due to pandemic covid 19. The results showed that slow learner is able to understand the concept of multiplying numbers through meaningful learning with problemsolving on student worksheets and test that linked previous mathematical understanding with a new understanding of the concept of multiplying numbers. This research can be used as alternative learning for other inclusive schools, especially for students with special needs with the same criteria.
\end{abstract}

Keywords: Multiplication of numbers, Slow Learner, Meaningful Learning, Understanding.

\section{INTRODUCTION}

Mathematics is one of the important subjects in elementary school. The purpose of learning mathematics in elementary schools according to [1] is to train thinking and reasoning in drawing conclusions, developing creative activities, developing problemsolving skills, and developing the ability to convey information or communicate ideas. Learning mathematics in elementary schools is expected that students will be able to find the necessary knowledge during the learning process.

One of the materials taught to second-grade elementary school students is multiplication. Multiplication of two numbers is a new basic competency for second-grade elementary school students, where the concept of multiplication is instilled as repeated addition. The basic ability to count the multiplication of two numbers 1 to 10 needs to be mastered by students since the second grade. This is because understanding the concept of multiplication is a prerequisite for studying further mathematics material. At this level, students are required to immediately master the concept of multiplication first so that it is easier for students to understand the next material

Based on preliminary observations, it was found that in the sixth grade of SDN Sumedangan 2 which consisted of normal students and one student with special needs, there were students who did not understand the concept of integer multiplication well. Students with learning disabilities are slow learners with speaking disabilities. Slow learners are distinguished from underachievers who experience learning difficulties as a result of absences from school, 
unfortunate personal circumstances, and inadequate environmental conditions rather than owing to their limited learning ability and from the learning disabled who have disorders in language, reading, and communication ability [2]. From the results of observations made and checking the initial understanding of students with special needs about the basic concept of multiplying numbers from 1 to 10 , namely $7 \times 8$, it was found that students still had difficulty operating the multiplication. This student is still counting using fingers to do repeated addition. However, the result obtained from the multiplication is still wrong. This results in a very low understanding of other mathematical materials. Students find it difficult to learn mathematics material in high classes because students' understanding of the multiplication material is still lacking [3].

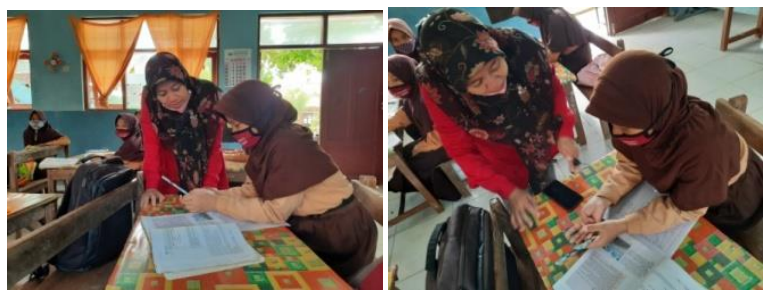

Figure 1. Preliminary Study in Sixth Grade of Elementary School Sumedangan 2 Pamekasan

Primary School Sumedangan 2 is one of the inclusive schools in Pamekasan, this school should implement inclusive education. Inclusive education is the provision of education that unites children with special needs with normal children, in general, to learn [4]. Inclusive education is an educational service provided for children with special needs in obtaining proper education [5]. Inclusive education is a combination of the implementation of special education with regular education in one unified education system [6]. So, inclusive education is the implementation of education and learning that includes students with special needs and normal students with the aim of equitable education.

However, the learning that is currently taking place at SDN Sumedangan 2 has not yet implemented an inclusion-based curriculum. Schools with inclusive education must have readiness in all respects, from the readiness of school principals, teachers, curriculum, infrastructure, and so on to support the implementation of inclusive education properly [7]. Based on the results of observations and interviews with teachers, it was found that the curriculum and learning for students with special needs were still equated with normal students or regular classes, there was no accompanying teacher for students with special needs, the lack of teaching aids used in mathematics learning, especially learning the concept of multiplying numbers, and learning often not linked to the daily life of students. This results in the learning achievement of students with special needs in the slow learning category which is very low even below average.

Based on the above problems, this study applies meaningful learning for slow learners with speaking disabilities. Meaningful learning will be carried out by providing assistance (scaffolding) to students who are slow to learn through familiar learning media to make it more attractive, and easily understood by students with special needs. This is in line with [8] that student learning saturation also appears when the learning media and mathematics learning process used by the teacher have nothing to do with the problems of students' daily life. The assistance or scaffolding that will be provided is in the form of domino learning media and clamshells media that students usually encounter in their daily life and the problems associated with students' lives. Scaffolding is an important tool for meetings the challenging needs of heterogeneous groups of students in inclusive classrooms. It is especially useful when supporting low achievers especially slow learners [9]. Scaffolding is providing assistance by teachers to students in the learning process at the right time and stopping assistance to give students the opportunity to take over responsibility after students are able to solve problems so they can achieve their goals [10].

Several studies on learning on slow learners in inclusion classes, namely (1) Hadi [11] examines learning mathematics for slow learners which includes teacher readiness before learning, implementation of learning, evaluation, and follow-up, as well as obstacles experienced by slow learners; (2) Hartini, etc. [12] stated that the model of project-based learning can be used as a selection model that can be modified in the design of learning strategies to cope with the slow learner in elementary school; (3) Wati [13] stated that slow learner students have good social interactions such as easily getting along with anyone; (4) Amdany, etc. [14] stated that the intrinsic and extrinsic learning motivation on Slow Learner student is high; (5) Labuem [15] stated that in the stage of understanding the subject's problem only remembers information at the end of the problem because of limited memory. In the stage of making a problem-solving plan, the subject translates the problem into mathematical symbols based on the sequence of activities in the problem. In the stage of implementing the problem-solving plan, the subject can solve existing problems but does not have confidence in the truth of the final answer obtained. In the stage of checking again, the subject does not recheck each step of completion or the final answer obtained because the subject considers the work to have been completed. Based on some of these studies, it shows that no one has researched meaningful learning at the slow learner to improve understanding of the multiplication concept of numbers in inclusive school students using domino and clamshells media. 
This study aims to describe in detail the meaningful learning through the use of domino media and clamshells in understanding the multiplication of numbers in the sixth grade of inclusion school SDN 2 Sumedangan Pamekasan. This means learning all the relevant skills and knowledge obtained can be utilized in everyday life [16]. This study provides special assistance for students who are slow learners so that their learning achievement increases and are able to understand mathematical concepts, especially multiplication of numbers.

\section{METHODS}

This study aims to describe in detail the meaningful learning through the use of domino and clamshells media in understanding the multiplication of numbers in the sixth grade of inclusion school Primary School Sumedangan 2 Pamekasan. This research uses a case study approach, to describe the characteristics of students with special needs in understanding the concept of multiplication and to analyze intensively various existing phenomena.

The research subject is a sixth-grade student with special needs in the slow learning category with speaking disabilities. Slow learners as students with below-average cognitive abilities who are not disabled, but who struggle to cope with the traditional academic demands of the regular classroom [17]. The weaknesses of the slow learners are (a) difficulty to understand abstract concepts, (b) limited speech or slow speech, (c) it takes time to understand the concept of multiplication. This student has studied the multiplication of numbers since the second grade, but he still doesn't understand the concept now. This research was conducted at the research subject's house due to the Covid 19 pandemic.

Researchers observed intensively learning the multiplication of numbers in students with special needs when using domino and clamshells learning media and tests in understanding the multiplication of numbers concept. The problems in the test contain problems in everyday life that students usually encounter.

The data analysis of this research uses several stages, namely: (1) identifying the data, (2) verifying the data of understanding the slow learner concept, (3) simplifying the data of understanding the slow learner concept, (4) summarizing or making a conclusion of understanding concept slow learner. The subjects were observed, tested, and interviewed. Observations were made on the multiplication of numbers learning process. The test aims to determine the level of understanding of the multiplication of numbers. While the interview aims to determine the level of understanding of the multiplication of numbers concept and the process of learning multiplication of numbers.

\section{RESULT AND DISCUSSION}

This research was conducted in 2 stages: (1) learning the multiplication of numbers concept, (2) evaluation of learning through tests and interviews.

\section{Learning the multiplication of numbers concept}

The learning of the multiplication concept of numbers for the slow learners was carried out at the student's house due to the Covid 19 pandemic. The researcher visited the research subject's house to carry out the learning process using domino media and clamshells. The subject of this study has understood the concept of adding numbers, but the difficulty is associated with the concept of multiplying numbers. The following is a learning activity about the concept of multiplying numbers using domino and clamshells media.
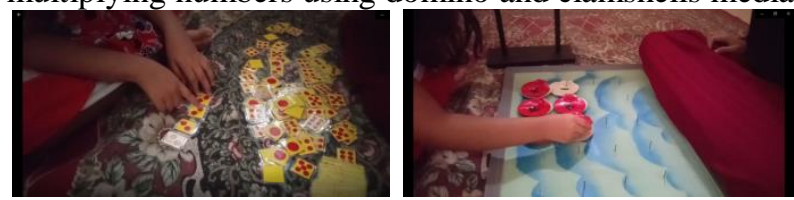

Figure 2. Number multiplication learning activity using domino media and clamshells

Domino media is used for the multiplication of simple numbers, namely the multiplication of positive and positive numbers, for example, $4 \times 2$. Meanwhile, the clamshell media is used for negative and positive multiplication, which is $-2 \times 3$; negative and negative multiplication.

In this activity, the research subjects were enthusiastic about learning by tinkering with the learning media that the students were familiar with. From this learning process, it makes it easier for slow learners with speaking limitations to understand the concept of multiplication. Mathematical concepts and ideas depart from the real world which is mathematical. From concrete experience, it is observed and reflected for the formation of abstract concepts and generalizations [18].

By connecting previous knowledge about the addition of integers which is then applied to the concept of multiplying numbers, the conceptual understanding of students' mathematics, especially students with special needs, can be formed well. This is according to the opinion of [10], Conceptual understanding can be done by building new knowledge based on prior knowledge that includes the concepts, operations, and relationships. With this activity students who are slow to learn can understand abstract concepts through concrete objects.

In addition to learning through domino and shellfish learning media, the research subjects were then given a worksheet to understand the multiplication of numbers. 

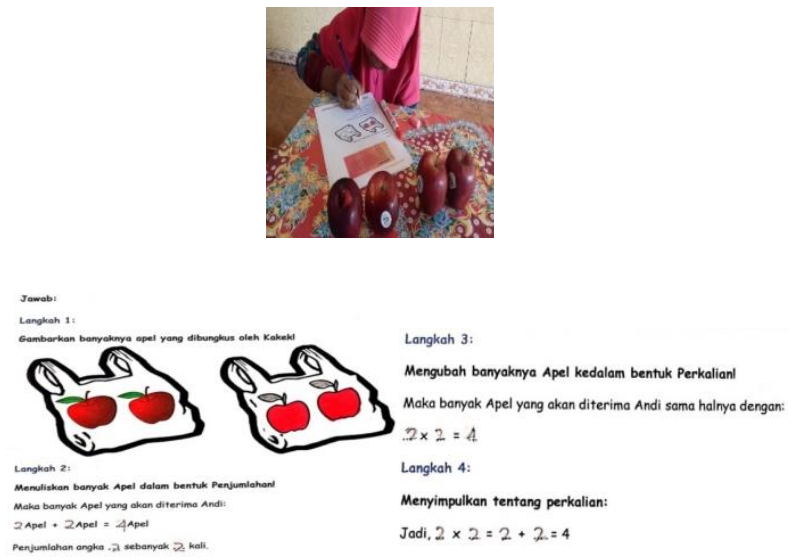

Figure 3. Answer of number 1 to the slow learner worksheet

The analysis of the work of research subjects in number 1 is as follows:

a) Thorough and able to understand in reading question number 1 so that they are able to remember and identify elements that are known in the problem and can retell the contents of the questions using their own language and be able to demonstrate with real objects as understood in the problem but does not change the aims and objectives that are asked in question number 1

b) Subjects are able to describe the concept of multiplication by showing pictures, writing, and mathematical forms and are able to complete according to the procedure for completion.

c) The subject is able to solve question number 1 well and there is no mistake whatsoever and is able to understand the problem and is able to retell it with real objects in front of him. So that the subject can be said to have understood the concept of integer multiplication.

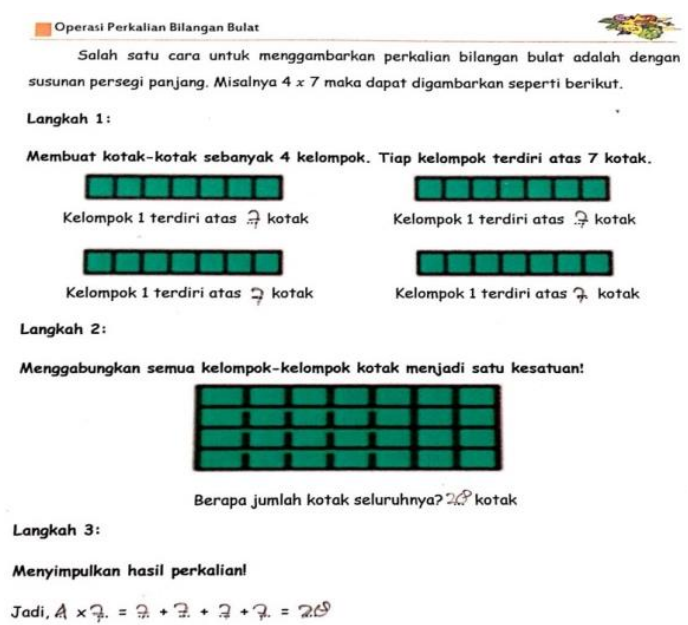

Figure 4. Answer of number 2 on the slow learner worksheet

Analysis of the work of research subjects in number 2 is as follows: a) Thorough and able to understand in reading question number 2 so that they are able to remember and identify elements that are known in the problem and can retell the contents of the question using their own language and be able to demonstrate with real objects as understood in the problem but does not change the aims and objectives asked in question number 2 .

b) The subject is able to describe the concept of multiplication with the instructions for pictures, writing, and mathematical forms and is able to complete in accordance with the complete procedure.

c) The subject is able to solve question number 2 well and there is no error whatsoever and is able to understand the contents of the question and can solve it with easy and understandable procedures and compare the answer with real objects and with pictures in the worksheet.

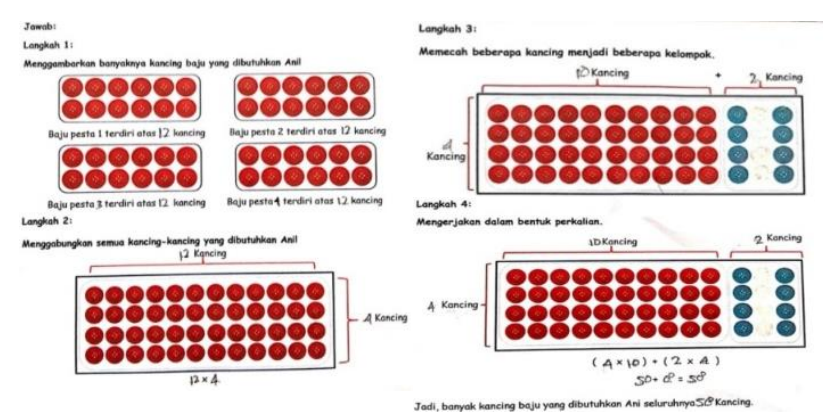

Figure 5. Answer of number 3 slow learner worksheet

The analysis of the work of research subjects in number 3 is as follows:

a) Thorough and able to understand in reading question number 3 so that they are able to remember and identify elements that are known in the problem and can retell the contents of the question using their own language and be able to demonstrate with real objects as understood in the problem but does not change the aims and objectives asked in question number 3 .

b) The subject is able to describe the concept of multiplication using the help of concrete objects provided, in writing, and mathematical form and is able to complete according to the procedure for completion.

c) The subject is able to solve problem number 3 well even though there is one error, namely when $(4 \times 10)$ writes 50. After being analyzed it turns out that the error is due to the inaccuracy factor of the subject in calculating the number of red buttons in the image and does not match or check again with the results.

By learning through concrete objects and worksheets that are linked to the daily lives of students, it can improve their conceptual understanding well and facilitate understanding of abstract concepts in 
mathematics. Conceptual understanding is an understanding that is not only about what must be done, but also explains why it is done [19]. Manipulatives mirror physical manipulatives as well as provide dynamic representations of other mathematical situations. The goal of using the Manipulatives is to engage learners in a way that will lead to a more indepth understanding of the concepts and to give them experience thinking about the mathematics that underlies the manipulatives [20].

\section{Evaluation of Learning Through Giving Tests and Interviews}

The test was given aimed to determine the level of understanding of the multiplication of numbers concept after learning using learning media that was linked to the daily lives of students. The problems in the test are also in the form of story questions with interesting pictures, making it easier for students to solve the problems in them because of the constraints of the limitations of students who are slow to learn in speaking. Interviews were conducted to check the extent of students' understanding in solving problems and their explanations on the test sheets. The following is a description of the analysis of the test results for each question and the interview for the slow learners.

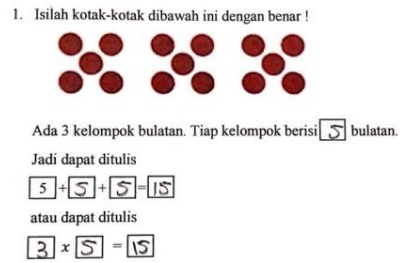

Figure 6. Answer of number 1 of the slow learner test

Analysis of the results of the test and interview number 1 slow learner as follows.

a) Thorough and able to understand in reading question number 1 so that they are able to remember and identify elements that are known in the questions and can retell the contents of the questions using their own language that can be understood by the subject.

b) The research subject is able to understand the problem in number 1 , this is proven by the subject who is able to solve problem number 1 well.

c) The research subject is able to describe the concept of multiplication by using writing and its mathematical form and is able to complete it according to the completion procedure. And also the subject began to be able to relate the concept of multiplication to the available images.

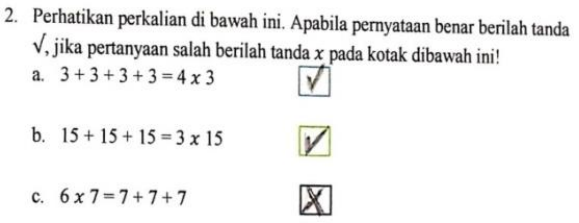

Figure 7. Answer of number 2 of the slow learner test
Analysis of the results of the test and interview number 2 slow learner as follows.

a) Thorough and able to understand in reading question number 2 so that they are able to remember and identify elements that are known in the questions and can retell the contents of the questions using their own language that can be understood by the research subjects.

b) Research subjects are able to understand the command questions, able to explain and answer correctly.

c) The research subject is able to provide reasons for the answer and is able to remember and relate it to the multiplication concept that he has understood.

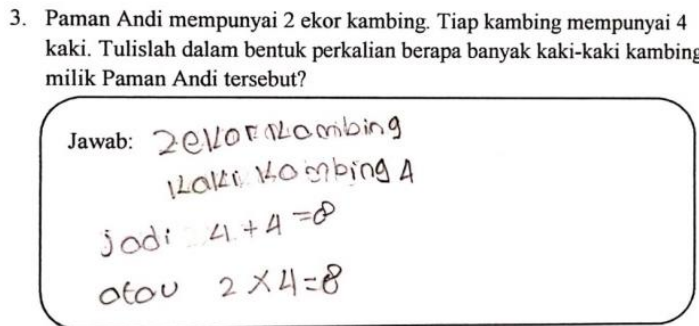

Figure 8. Answer of number 3 of the slow learner test

Analysis of the results of the test and interview number 3 slow learner as follows.

a) The research subjects are thorough and able to understand in reading question number 3 so that they are able to remember and identify known elements in the questions and can retell the contents of the questions using their own language that can be understood by the subject.

b) The research subject is able to understand the question commands and is able to provide correct answers according to what the previous subject understood about the concept of multiplication.

c) The research subject is able to provide reasons for the answer and is able to use the concept of multiplication well and is able to describe the contents of the question and the solution to question number 3 well.

Based on the results of the test sheet, from the three questions given, it was seen that the subject answered correctly and was able to present it in a mathematical form even though there was no assistance using concrete objects. This is a form of evaluation of previous learning that uses concrete objects and is connected to the daily life of students. This form of learning is a meaningful learning that produces an organized mathematical model that allows research subjects to make conclusions and apply their knowledge. Meaningful learning is thought to produce organized, coherent, and integrated mental models that allow people to make inferences and apply knowledge [21]. Students must learn mathematics with understanding actively building new knowledge from experience and prior knowledge [20], So, based on learning outcomes using learning media, worksheet 
work results, test sheet results, and interview results from research subjects it is concluded that research subjects have understood the concept of multiplying numbers well. It goes on to say that evidence of students' understanding of a concept is their ability to apply that concept to novel situations, as an act (of grasping the meaning) and not as a process or way of knowing [22][23].

The results of this study indicate that the use of domino and clamshells as learning media in understanding the multiplication of integers is very effective for slow learners in inclusive schools. Through this learning, the slow learner is able to learn meaningfully based on the stages of Bruner's learning theory through concrete (enactive) media, worksheets (iconic), and evaluation in solving problems related to number multiplication (symbolic) so that the abstract concept of integer multiplication can be well understood.

\section{CONCLUSION}

Based on the results of the research, it can be concluded that the subject of this study, namely one slow learner student in the inclusion class, can understand the concept of multiplying numbers well through meaningful learning, namely the manipulation of concrete objects with dominoes and clamshells as learning media, and linking learning with daily activities through worksheets, and learning evaluations through tests and interviews which are also linked to students' daily lives. From the research results it can be concluded::

a) Slow learner is able to understand the concept of multiplying positive integers with positive integers, positive integers with negative integers, negative integers with negative integers through the concrete objects of dominoes and clam shells.

b) Slow learner is able to solve problems based on the steps given in the worksheet so that learning is meaningful.

c) Slow learner is able to solve problems on the test and is able to explain again using his own language so that the slow learner can understand the concept of multiplication well.

This research can be used as alternative learning for other inclusive schools, especially for students with special needs with the same criteria.

\section{REFERENCES}

[1] B. Sudibyo, "Peraturan Menteri Pendidikan Nasional (Permendiknas) Republik Indonesia Nomor 22 Tahun 2006 tentang Standar Isi untuk Satuan Pendidikan Dasar dan Menengah," in PERATURAN MENTERI PENDIDIKAN NASIONAL REPUBLIK INDONESIA, 2006, pp. $1-48$.

[2] T. Tran, T. T. T. Nguyen, T. T. T. Le, and T. A. Phan, "Slow learners in mathematics classes: the experience of Vietnamese primary education," Educ. 3-13, vol. 48, no. 5, pp. 580596, 2020, doi: 10.1080/03004279.2019.1633375.

[3] K. Badriyah, "Peningkatan Pemahaman Konsep Penjumlahan 1 Sampai 10 melalui Model Pembelajaran Quantum Teaching pada Anak Tunagrahita Ringan Kelas III SLB Ma'arif Bantul," J. Ilm. Mhs. Widia Ortodidaktika, vol. 5, no. 4, pp. 1-11, 2016, [Online]. Available: http://journal.student.uny.ac.id/ojs/index.php/pl b/article/view/1732/1519.

[4] J. D. Smith, M. Baihaqi, M. Sugiarmin, N. Enrica, and Denis, Inklusi Sekolah Ramah untuk Semua. Bandung : Nuansa, 2006.

[5] J. C. Pratiwi, "Sekolah Inklusi Untuk Anak Berkebutuhan Khusus: Tanggapan Terhadap Tantangan Kedepannya," Pros. Semin. Nas. Pendidik. "Meretas Sukses Publ. Ilm. Bid. Pendidik. J. Bereputasi," no. November, pp 237-242, 2015.

[6] W. Wahyudi and R. Kristiawati, Gambaran Sekolah Inklusif di Indonesia: Tinjauan Sekolah Menengah Pertama. 2016.

[7] U. R. Jannah, H. Saleh, and A. Wahidah, "Scaffolding untuk Pembelajaran Matematika di Kelas Inklusi," J. Kaji. Pendidik. Mat., vol. 5, no. 1, pp. 61-72, 2019.

[8] Y. L. U.R. Jannah, M. Amiruddin, "GURU SEKOLAH DASAR DI KECAMATAN PADEMAWU “ WORKSHOP PEMBUATAN MEDIA DAN PEMBELAJARANNYA DENGAN MENGGUNAKAN KERANG,' Abdiku J. Pengabdi. Kpd. Masy., vol. 1, no. 1, pp. 26-39, 2018.

[9] M. Pfister, E. Moser Opitz, and C. Pauli, "Scaffolding for mathematics teaching in inclusive primary classrooms: a video study," ZDM - Math. Educ., vol. 47, no. 7, pp. 10791092, 2015, doi: 10.1007/s11858-015-0713-4.

[10] U. R. Jannah, T. Nusantara, Sudirman, Sisworo, F. E. Yulianto, and M. Amiruddin, "Student's learning obstacles on mathematical understanding of a function: A case study in Indonesia higher education," TEM J., vol. 8, no. 4, pp. 1409-1417, 2019, doi: 10.18421/TEM8444.

[11] F. R. Hadi, "Proses Pembelajaran Matematika Pada Anak Slow Learners (Lamban Belajar)," Prem. Educ. J. Pendidik. Dasar dan Pembelajaran, vol. 6, no. 01, pp. 35-41, 2016, doi: 10.25273/pe.v6i01.295.

[12] A. Hartini, D. Widyaningtyas, and M. I. Mashluhah, "Learning Strategies for Slow Learners Using the Project Based Learning Model in Primary School," JPI (Jurnal Pendidik. Inklusi), vol. 1, no. 1, p. 29, 2017, doi: 10.26740/inklusi.v1n1.p29-39.

[13] R. D. Wati, "Interaksi Sosial Siswa Slow Learner," J. Pendidik. Sekol. Dasar, vol. 7, no. 3, pp. 266-273, 2018. 
[14] P. Amdany, S. Sularmi, and M. I. Sriyanto, "Learning Motivation of Slow Learner in Elementary School," Soc. Humanit. Educ. Stud. Conf. Ser., vol. 1, no. 1, pp. 613-618, 2018, doi: 10.20961/shes.v1i1.23506.

[15] S. Labuem, "the Thinking Process of Children With Special Needs (Slow Learner) in Inclusion Classes in Solving Mathematical Problem," JUPITEK J. Pendidik. Mat., vol. 2, no. 2, pp. 43-50, 2020, doi: 10.30598/jupitekvol2iss2pp43-50.

[16] A. C. Kean and N. M. Kwe, "Meaningful Learning in the Teaching of Culture: The Project Based Learning Approach," J. Educ. Train. Stud., vol. 2, no. 2, pp. 189-197, 2014, doi: $10.11114 /$ jets.v2i2.270.

[17] E. Canter, Andrea S., Ed.; Carroll, Servio A., "Helping children at home and school: Handouts from your school psychologist," in The National Association of School Psychologists, 1998.

[18] K. Cummings and K. Cummings, "How Does Tutoring to Develop Conceptual Understanding Impact Student Understanding ?," 2015.

[19] U. Jannah, "Teori dienes dalam pembelajaran matematika," Interaksi, vol. 8, no. 2, pp. 126131, 2013.

[20] G. L. Musser, Peterson, E. Blake, Burger, F, Wiliiam, Mathematics for Elementary Teachers: A Contemporary Approach, 10th editi. United States of America: WileyPlus, 2014.

[21] J. D. Karpicke, "Retrieval-Based Learning: Active Retrieval Promotes Meaningful Learning," Curr. Dir. Psychol. Sci., vol. 21, no. 3, pp. 157-163, 2012, doi: $10.1177 / 0963721412443552$.

[22] E. Hoosain, "What Does it Mean to Understand Mathematics?," Humanist. Math. Netw. J., vol. 1, no. 25, pp. 20-22, 2001, doi: 10.1207/s15516709cog0403_1.

[23] A. Sierpinska, "Some Remarks on Understanding in Mathematics.," Learn. Math., vol. 10, no. 3, pp. 24-36, 1990. 